\title{
Ethics in the Message of Isaiah
}

\author{
Aaron H. Y. Chan* \\ *Penulis adalah pengajar bidang Perjanjian Lama di STT-SAAT, Jl. Bukit Hermon 1, Malang. \\ Email: aaronchan@seabs.ac.id
}

\begin{abstract}
Abtract: Form-critical studies in the ethical basis of Isaiah has reached an impasse. Many ethical injunctions in Isaiah 1-39 does not fit into either wisdom or legal categories according to form-critical approaches. This article will re-examine the ethical basis of Isaiah 1-39 by employing a literary-canonical approach.
\end{abstract}

Keywords: OT Ethics, Ethics, Prophecy and Law, Isaiah's ethics

\begin{abstract}
Abstrak: Studi kritik bentuk mengenai dasar etika dalam kitab Yesaya telah mencapai kebuntuan. Banyak perintah etis dalam Yesaya 1-39 tidak dapat digolongkan baik ke dalam kategori hikmat atau hukum menurut pendekatan-pendekatan kritik bentuk. Artikel ini akan meninjau ulang dasar etis dalam Yesaya 1-39 dengan menggunakan pendekatan literer-kanonis.
\end{abstract}

Kata-kata kunci: Etika PL, Etika, Nubuat dan Taurat, Etika Yesaya 


\section{Introduction}

To speak of ethics of Isaiah is to speak of a difficult, complex, and neglected subject. Eryl W. Davies, in the 1980s, lamented that "few attempts have been made in recent years to analyze, in any systematic manner, the ethics of the Old Testament, especially as it relates to the teaching of the eighth-century prophets."1 While studies on ethics in the prophetic corpus have focused primarily upon the sources of the prophet's ethical tradition, there are relatively few studies that have focused upon the basis of prophetic ethics. ${ }^{2}$

Proposing a late date for the Deuteronomic laws, Julius Wellhausen saw the prophets as founders of ethical monotheism and thus the prophets are the ones who provided the basis for Israelite ethics. ${ }^{3}$ According to the Wellhausanian stream of interpretations, the prophets were ecstatic recipients of divine secrets who proclaimed an ethical monotheism received directly from God. ${ }^{4}$ Thus, the prophetic ethical ideals were thought to have originated directly from the prophets themselves without any dependence upon other traditions.

With the rise of Form Criticism, the Mendanhall school questioned the late dating of the Pentateuch and challenged the concept of the prophets as the pioneers of ethical monotheism. ${ }^{5}$ This corrective of Wellhausanian inter-

${ }^{1}$ Eryl W. Davies, Prophecy and Ethics: Isaiah and the Ethical Traditions of Israel, vol. 16, Journal for the Study of the Old Testament Supplement Series (Sheffield: JSOT, 1981), 9 .

${ }^{2}$ See ibid., 12-24, for a brief survey of past approaches.

${ }^{3}$ See Julius Wellhausen, Prolegomena to the History of Israel (Edinburgh: Adam \& Charles Black, 1885), 474. These ethical ideals were later codified as Deuteronomic laws, which in turn abolished the need for the prophetic ministry (see ibid., 487-88). For an assessment on Wellhausen's theories, see Patrick D. Miller, Israelite Religion and Biblical Theology: Collected Essays (Sheffield: Sheffield Academic Press, 2000), 182-196.

${ }^{4}$ See for example J. Lindblom, Prophecy in Ancient Israel (Oxford: Blackwell, 1962).

${ }^{5}$ George E. Mendenhall, "Covenant Forms in Israelite Tradition," The Biblical Archaeologist 17, no. 3 (1954): 49-76. pretations asserted an early dating of the Pentateuch and emphasized that the prophets were enforcers of the Sinaitic covenant; they championed the ethical requirements of the covenant upon Israel. Thus, the prophets were no longer seen as ethical innovators. Rather, as R. E. Clements asserts, they were "heirs of a very rich tradition" of which "the central focus of such a tradition was the belief in a covenant between Yahweh and Israel." 6 Further, Gerhard von Rad argued that the $8^{\text {th }}$ century prophets were rooted in a complex mix of Sinaitic and Zion traditions. ${ }^{7}$

Others, however, questioned the proposal that a legal-covenantal tradition was indeed behind the ethics of the prophets. ${ }^{8}$ John Barton notably pointed out that prophets like Isaiah spoke against "actions and attitudes not mentioned in the law" (such as excessive luxury [Isa 3:16, 4:1]; drunkenness [Isa 5:1117, 22; 28:1-14]). ${ }^{9}$ Barton is convinced these non-legal injunctions are indebted to wisdom's influence. ${ }^{10}$

Davies also calls for a reassessment of this issue since, in his words, "the debate concerning the relation of the prophets to tradition has reached something of an impasse."11 Employing a form critical analysis, he investigated the possibility of a legal, wisdom, and prophetic tradition as source of prophetic ethics (based upon Amos). ${ }^{12}$ He concludes that "it is difficult to identify with any certainty

${ }^{6}$ R. E. Clements, Prophecy and Covenant, Studies in Biblical Theology No. 43 (Naperville: Allenson, 1965), 15.

${ }^{7}$ Gerhard von Rad, Old Testament Theology (Louisville: WJK, 2001), 2:178-187.

${ }^{8}$ Eryl Davies cites D. J . McCarthy, Treaty and Covenant: A Study in Form in the Ancient Oriental Documents and the Old Testament, An. Bib. 21 (Rome, 1963) and Lothar Perlitt, L. Bundestheologie im Alten Testament, WMANT 36, (Neukirchen: Neukirchener Verlagsgesellschaft, 1969) as examples of those who questioned the covenantal tradition.

${ }^{9}$ John Barton, Understanding Old Testament Ethics: Approaches and Explorations (Louisville: WJK, 2003), 132.

${ }^{10}$ Ibid.

${ }^{11}$ Davies, Prophecy and Ethics, 23.

${ }^{12}$ Davies questioned if Isaiah's indictment of the people employs terminologies of suzerain-vassal covenant treaty. 
the source of the prophet's moral instruction" and that each individual prophet most probably borrowed from the "total culture in which he lived". ${ }^{13}$ This in turn led Davies to a somewhat agnostic conclusion that, "while Isaiah does exhort and admonish his hearers, this is almost always done in ad hoc fashion in relation to the specific situations with which he was confronted."14

In summary, studies on the source of prophetic ethics have tended toward a rejection of the legal-covenantal model, in preference of a more "ad hoc" model. In an attempt to reconcile the presence of legal and wisdom elements in Isaiah, Barton argues that natural law serves as a basis for Isaiah's ethics. Barton's proposal will be examined in further detail below.

There are several factors that raise the need for further study of the basis of Isaiah' ethics. First, studies on the sources of prophetic ethics have become intertwined with the basis of prophetic ethics. Barton clarifies that the search for the basis of prophetic ethics is not so much the search for the sources of influence behind, or the social setting leading up to the prophets' moral demand and stricture. Rather, it is that which the prophet "took or assumed to underlie the particular norms whose transgression he condemned, what he thought was so sinful about sins." 15 In a similar vein, Gordon J. Wenham asserts that what interests scholarship in the study of the basis of OT ethics is "the stance of the biblical writers to the deeds they describe."16 However, form-critical studies tend to make a conjectural leap from the sources behind prophetic ethics to making conclusions about the basis of prophetic ethics.

Secondly, Davies' assessment, like others before him, predicates a sharp distinction

${ }^{13}$ Ibid., 119.

${ }^{14}$ Ibid.

${ }^{15}$ Barton, Understanding Old Testament Ethics, 132-133.

${ }^{16}$ Gordon J. Wenham, Story As Torah: Reading Old Testament Narrative Ethically (Grand Rapids: Baker Academic, 2004), 6. between wisdom and law. However, recent studies demonstrate that wisdom is much more integral to the concept of law in the Ancient Near East than earlier form critics tended to acknowledge. ${ }^{17}$ Roland Murphy has suggested that "the problem of the relationship between Wisdom literature and other portions of the Old Testament needs to be reformulated in terms of a shared approach to reality." 18 Moreover, Davies' negative conclusions are more telling about the limitations of form critical analyses per se than the nature of prophetic ethics. ${ }^{19}$

Thirdly, a synchronic study on this issue may be a more viable way forward through the "impasses" reached by proponents of diachronic approaches. Brevard Childs rightly asserts that an overemphasis on diachronic analysis, which focuses on identification of sources and redaction layers, neglects the fact that the Isaianic texts (as well as the Pentateuch) comes to us in its final canonical form, written as a "coherent witness" for the community of faith. ${ }^{20}$ This means that the final form of the text was meant to be read as it stands rather than in its fragments, sources or forms..$^{21}$ Furthermore, recent development in the studies of OT laws highlights the importance of understanding these laws within their

${ }^{17}$ See John H. Walton, Ancient Near Eastern Thought and the Old Testament: Introducing the Conceptual World of the Hebrew Bible (Grand Rapids: Baker Academic, 2006), 295-298. For a discussion on the relationship between law and wisdom, see Craig G. Bartholomew, Baker Commentary on the Old Testament: Ecclesiastes, ed. Tremper Longman III (Grand Rapids: Baker Academic, 2009), 84-93.

${ }^{18}$ R. E. Murphy, "Wisdom - Theses and Hypotheses," in Israelite Wisdom: Theological and Literary Essays in Honor of Samuel Terrien, ed. J. G. Gammie (Missoula: Scholars. 1978), 38.

${ }^{19}$ For a critique of form/genre comparative analysis, see Kenton L Sparks, Ancient Texts for the Study of the Hebrew Bible: A Guide to the Background Literature (Peabody: Hendrickson, 2005), 10-11.

${ }^{20}$ See Brevard S. Childs, Isaiah: A Commentary, ed. William P. Brown, Carol A. Newsom, and Brent A. Strawn, 1st ed, The Old Testament Library (Louisville: WJK, 2001), 3-4.

${ }^{21}$ However, Child's is also critical of an overly synchronic approach which neglects diachronic analysis (see Childs, Isaiah, 11). 
narrative frameworks. For example, James W. Watt argued that the lack of systematic codification of OT laws and their "placement within stories" meant that they were to be read "within the narrative plot sequence." 22 Form-critical approaches were based largely upon a comparison between legal formulation and citations between prophets and the law. Such approaches unwittingly imposed modern legal concepts on ancient texts. ${ }^{23}$ They also ignore the possibility that prophets can refer to the Mosaic laws "periphrastically and paraenetically as opposed to verbatim." ${ }^{24}$ In addition, following Bernard Jackson's landmark study on the semiotics of Biblical Law, Jonathan Burnside highlights the anachronisms of a "legislative model" of biblical law resulting in a "semantic view of law." 25 Accordingly, a semantic view of law sees the "very words, as opposed to its meaning [or significance]," of legal statutes as authoritative and binding. ${ }^{26}$ "The law then applies to all cases falling within the semantic meaning of the words." 27 Burnside argues that a legislative view of the law is a modern imposition on the biblical text. ${ }^{28}$ In contrast, similar to "ANE legal praxis," biblical law has a didactic, rather than a legislative, function. ${ }^{29}$ With Bernard Jackson, Burnside argues that a narrative approach to biblical law is more consistent with biblical legal praxis than a semantic approach. ${ }^{30}$ Thus, a synchronic reading of the laws within their narrative context can illumi-

${ }^{22}$ James W. Watts, Reading Law: The Rhetorical Shaping of the Pentateuch (Sheffield: Sheffield Academic, 1999), 11.

${ }^{23}$ See Bernard S. Jackson, Studies in the Semiotics of Biblical Law, vol. 314, JSOT Supplement Series (Sheffield: Sheffield Academic, 2000).

${ }^{24}$ Douglas Stuart, “The Old Testament Prophets' Self Understanding of Their Prophecy," Themelios 6, no. 1, (September 1980): 10-11.

${ }^{25}$ Jonathan P. Burnside, The Signs of Sin: Seriousness of Offence in Biblical Law, vol. 364, JSOT Supplement Series (Sheffield: Sheffield Academic, 2003), 15.

${ }^{26}$ Ibid.; brackets mine.

${ }^{27}$ Ibid.

${ }^{28}$ Ibid., 10-15.

${ }^{29}$ Ibid., 14.

${ }^{30}$ Ibid., 16. nate the meanings and significance of those laws and, beyond that, their relationship to the prophet's ethical ideals. ${ }^{31}$

This article is meant to contribute to the discussion about the ethical basis of the eighth century prophets particularly as it relates to the message of the prophet Isaiah. The approach to formulate an understanding of the ethical basis of Isaiah the prophet will be based upon a synchronic reading of Isaiah 1-39. Of significance for this study is the fact that there exists a consensus among scholars of the authenticity of the passages dealing with morality in Isaiah 1-39; these passages remain undisputed. ${ }^{32}$ Furthermore, this study holds in high regard the canonical ordering of the Hebrew Scriptures and, with that, assumes that Isaiah (or his redactors) would have "known" the "earlier" texts within the canon as in the canonical rendering of "Law and prophets" (Matt 7:12; 22:40; Luke 16:16; Acts 13:15).

\section{Survey of Isaiah's Indictments}

Isaiah begins his message with a general charge that God's people had rebelled against YHWH. YHWH's children (דָָּּנים), His people (פ), had forsaken YHWH and turned their backs on him (1:4-5). She had bitten the hand that rocks her cradle and turned against YHWH who brought her up. She had failed to recognize her owner (1:2-3). For that, Isaiah makes it clear that they already have, and in their future will, suffer the consequences of their rebellion (1:5-9). Despite their stiffnecked rebellion, and in spite of the repeated warnings, the people of God had continued prostituting themselves in their religious practices. YHWH denounced such practices as abomination to Him (1:10-17) since they prayed to Him with blood filled hands (1:15). Commentators debate the meaning of the word דִָּּים (blood) in verse 15. Does it refer to the blood of vain sacrifices or does it refer to

\footnotetext{
${ }^{31}$ See J. G. McConville, Law and Theology in Deuteronomy, vol. 33, JSOT Supplement Series (Sheffield: JSOT, 1984) and Christopher J. H. Wright, Old Testament Ethics for the People of God (Downers Grove: Inter-Varsity, 2004).
}

${ }^{32}$ See Barton, Understanding Old Testament Ethics, 131. 
the blood from violence and injustice? ${ }^{33}$ From the preceding context of verses 16-17, it seems that the latter meaning is more plausible. Isaiah employs the cultic language of worship to pave the way for a striking irony. Instead of worshipping God with acceptable sacrifices, their hands were filled with blood from violence. ${ }^{34}$ Verses 16 and 17 elaborate the nature of their blood violence by juxtaposing active and passive participation of evil deeds. The active sense involves outright violence and oppression $^{35}$ while the passive sense involves a neglect of social justice. ${ }^{36}$ In short, the people of God was charged with the sins of commission and omission. Thus, from the outset of Isaiah's message, we can see that his ethical basis draws on both a negative accusation and a positive demand. From this point on in the text, Isaiah frequently juxtaposes what the Israelites ought not to do and what they ought to do.

Although Isaiah starts off with an emphasis on social injustice, he is not fixated on it. The prophet proceeds to uncover the people's failure in the political and religious sphere. This point needs to be examined more closely within the social, political and religious sphere of Isaiah's address. ${ }^{37}$ These three areas are so intertwined that, at times, it is difficult to distinguish between them. Nevertheless, it is to that task that this study turns.

${ }^{33}$ For a cultic interpretation, see John Peter Lange, Philip Schaff, et al., A Commentary on the Holy Scriptures: Isaiah (Bellingham: Logos Bible Software, 2008), 41. For a blood-violence interpretation, see Gary V. Smith, Isaiah 1-39, ed. E. Ray Clendenen, The New American Commentary (Nashville: Broadman \& Holman, 2007), 108 and John Oswalt, The Book of Isaiah, Chapters 1-39, NICOT (Grand Rapids: Eerdmans, 1986), 98.

${ }^{34}$ Childs, Isaiah, 19.

${ }^{35}$ This can be seen in the charge to removal those deeds from their midst, "Take your evil deeds out of my sight! Stop doing wrong, learn to do right" (1:16).

${ }^{36}$ This can be seen in the exhortation toward good works, "Seek justice, encourage the oppressed. Defend the cause of the fatherless, plead the case of the widow" (1:17).

${ }^{37}$ See John Barton, "Ethics in Isaiah of Jerusalem," Journal of Theological Studies 32 (1981): 6.

\section{Righteousness and Justice}

After making a general statement about the Israelites' rebellion as YHWH's people and children (1:2-17), followed by an urgent call to a wise decision for repentance (18-20), Isaiah laments the sorry state of their morality as evidenced in their capital city, Zion (cf. 1:27): ${ }^{38}$

"How she has become a harlot, o faithful city. She was full of justice! Righteousness once lodged in her, but now murderers.

Your silver has become dross, your drink diluted with water.

Your rulers are rebels and companions of thieves; everyone loves a bribe and chases after rewards. They do not defend the orphan, nor does the widow's plea come before them." (Isa 1:2123.)

This passage clearly depicts Isaiah's vision of what Zion ought to be and the mourning that arises because of their departure from that moral standard. ${ }^{39}$ She ought to have been a city filled with justice מששפט and righteousness צדקה. On the contrary, murderers lived there. This passage provides a succinct description of how God's people had departed from משפט and צדקה. From rulers to commoners, the צדקה antire nation had turned from מששפט and embraced violence and oppression. Similarly in the Song of the Vineyard, the Lord looked for משפטת but משרקה but משה but found found (5:7). The use of assonance here deliberately sets up a contrast of what God's people ought to do and what they were doing, and zooms in on their on social relations. The movement from failure in divine relationships

${ }^{38}$ See Oswalt, The Book of Isaiah, 104-105, on the analysis of the poetic features of this verse. Verses 21-23 takes the form of a lament or a dirge as part of an overall prophetic judgment speech against the Jerusalemites. See Marvin Sweeney, Isaiah 1-39: With an Introduction to Prophetic Literature, vol. 16, The Forms of the Old Testament Literature (Grand Rapids: Eerdmans, 1996), 85, and Childs, Isaiah, 20.

${ }^{39}$ Notice the use of the adversative accompanied by the temporal adverb עַ עa the end of verse 21. This serves to highlight the contrast between Israel's present state and the state which Isaiah clearly identifies as the ideal. 
to social relations indicates "the outcome of infidelity to the Lord is infidelity to people." 40

Righteousness and justice are key concepts in Isaiah. משפט occurs a total of 42 times in the entire book. צדק is occurs 31 times while its parallel form צרפט s מרקה some 36 times. and צדק occur together about 5 times while and צדקה משיק occur together about 11 times. The concepts of righteousness and justice are expansive enough to warrant a detailed study. However, this article will only provide a brief survey regarding the scope and definition of these two concepts.

Righteousness and justice are assumed to be at home in Jerusalem. ${ }^{41}$ These two words embodies the ethical ideals of a renewed kingdom and people. They are highlighted as the qualities possessed by the true Davidic king (16:5; 32:1). These qualities are possessed by God who will take the initiative himself to restore these qualities to His people (5:16; 26:9; 33:5). Furthermore, justice and righteousness are hailed as qualities that will eventually be perpetuated to even the remotest parts as well as bring life and fertility in its wake (32:16). Here, the loss of both righteousness and justice in YHWH's faithful city then fuels Isaiah's indictment against the Israelites. $^{42}$ He spares no efforts to bring across their failure to maintain משדקה משתט (1:21; $5: 7)$. As a result of their failure, they would incur the wrath of God (28:17).

From a brief survey of the concepts of both righteousness and justice and their occurrence in Isaiah, one notices that these two words often occurs together and are complementary in their meanings. Moshe Weinfeld identified the two words as a hendiadys which expressed the concepts of social justice in Ancient Isra-

${ }^{40}$ J. A. Motyer, The Prophecy of Isaiah: An Introduction \& Commentary (Downers Grove: Inter-Varsity, 1996), Isa $1: 21$.

${ }^{41}$ Albert Barnes, Notes on the Old Testament: Isaiah (London: Blackie \& Son, 1851), 1:74.

${ }^{42}$ Barnes takes the mention of harlotry in 1:21 as a reference to idolatry, which is the focus of Isaiah's indictment (see Barnes, Isaiah, 74). el. ${ }^{43}$ Building upon Weinfeld's study on the word pair, Leclerc pointed out that whether they are used in sequence or reversed, whether they are joined with conjunction or split for parallelism, they both functioned as a hendiadys and entailed the concept of social justice. ${ }^{44}$ However, this does not override the distinct meaning of each word. Their occurrence together meant that an abstraction of ethical ideal may be in view.

Perhaps a better way to understand what Isaiah meant by the two terms is to see the charges laid out against God's people. This was often the case as they were berated for their departure from the ethical ideal of righteousness and justice. In this study, it is important to point out that Isaiah, at times, explicitly referred to the concept of righteousness and justice and linked them to specific and concrete crimes. At other times, he makes implicit references to righteousness and justice in relation to specific sins. This study will examine the explicit use of this concept and explore its implicit use by means of inference.

With explicit reference to righteousness and justice, Isaiah condemned the Israelites for their: (a) oppressive treatment of widows and orphans (1:21-3); (b) their pursuit for ill-gotten gains (theft) and bribery (1:23); (c) greedy appropriation of land belonging to the poor $(5: 8-10) ;{ }^{45}$ (d) their neglect of the needs of the hungry and of the thirsty $(32: 6) ;{ }^{46}$ (e) their malice and slander (32:7); and (f) the outright

\footnotetext{
${ }^{43}$ Moshe Weinfeld, Social Justice in Ancient Israel and in the Ancient Near East (Jerusalem: Magnes, 2000), 25.

${ }^{44}$ Thomas Leclerc, Yahweh is Exalted in Justice: Solidarity and Conflict in Isaiah (Minneapolis: Fortress, 2001), 11-13.

${ }^{45}$ The entire pericope in 5:8-17 can be seen as an indictment against Israel's failure in righteousness and justice. The theme of justice and righteousness was brought to fore in 5:7 and the subsequent indictments shows how Israel has substituted justice and righteousness with oppression. In addition, after the pronouncement of judgment on Israel's sins, Isaiah declares that in spite of Israel's failure, the LORD himself is exalted in justice and righteousness $(5: 16)$.

${ }^{46}$ The entire chapter 32 can be seen as the expression of the divine kingly ideal of righteousness and justice and the antithesis of it.
} 
enactment of laws that deprive justice and rights to those who needed it most (10:1-2).

I will argue below that even without an explicit reference to the word pair, Isaiah pointed out the way of righteousness and justice by condemning the people of their "excessive luxury and personal adornment" 47 (3:16-26; 9:912) and their drunkenness which is tied to a neglect of justice and righteousness (5:11-12; 28:1-17). Thus, the ethical ideal of justice and righteousness encompassed how the Israelites should treat the economically deprived, their attitude towards ill-gotten gains, their stewardship of legitimately owned wealth, as well as legislation and the sins of bearing false witness. We shall examine the meaning of each term and then examine their relationship to specific indictments including those without explicit mention of the notion of righteousness and justice.

Righteousness is, first of all, a moral concept. Mark Seifrid observed that צדקה בדי צ' is "more often found in parallel with terms for rectitude or in opposition to terms for evil, expressing approbation or condemnation."

${ }^{48}$ Righteousness is also a relational concept. Following von Rad, Bruce Birch observed that in the Old Testament, צדקה צדי, entail not a set of norms, but right conduct that flows out of an established relationship; in the Israelite's case - a covenantal relationship with God. ${ }^{49}$ However, von Rad's rejection of righteousness as an absolute ethical norm since "ancient Israel did not in fact measure

\footnotetext{
${ }^{47}$ Barton, "Ethics in Isaiah of Jerusalem," 6.

${ }^{48}$ Mark A. Seifrid, "Righteousness Language in the Hebrew Scriptures and Early Judaism," in Justification and Variegated Nomism: The Complexities of Second Temple Judaism, ed. D. A. Carson and Peter T. O'Brien, 140th ed., vol. 1, Wissenschaftliche Untersuchungen Zum Neuen Testament (Grand Rapids; Tübingen: Baker Academic; Mohr Siebeck, 2001), 424. See also John Skinner, "RIGHTEOUSNESS IN OT," in A Dictionary of the Bible: Dealing with Its Language, Literature, and Contents Including the Biblical Theology, ed. James Hastings et al. (New York; Edinburgh: Charles Scribner's Sons; T. \& T. Clark, 1911-1912), 273.

${ }^{49}$ Bruce Birch, Let Justice Roll Down: The Old Testament, Ethics and Christian Life (Louisville: WJK, 1991), 153-155.
}

a line of conduct or an act by an ideal norm, but by the specific relationship in which the partner had at the time to prove himself true" is overstated. ${ }^{50}$ To be sure, an absolute ethical norm apart from the "fear of god" is foreign to the ANE world. ${ }^{51}$ But one should not drive a wedge between "absolute" normativity and its relational base. Von Rad's admission that "the specific relationship in which the agent finds himself is itself the norm" proves that such dichotomy is needless. ${ }^{52}$ Seifrid also notes that "where 'righteousness' is joined to such ideas as 'truth' and 'uprightness,' it is clear that the idea of a standard or norm is included in the concept (e.g. $1 \mathrm{Kgs} \mathrm{3:6}$; Isa 45:19; 48:1; Ps 119:142)." ${ }^{53}$ Thus, instead of stating that righteousness is "'relational' and not "normative," "it is more accurate to conclude that the biblical concepts often involve the idea of justice in application, i.e. a norm or standard expressed within a particular relationship." 54

Furthermore, righteousness is also a creational concept. Seifrid argues that "righteousness" is simultaneously both moral and creational, having to do with God's re-establishing "right order" in the fallen world which he has made, an order which includes a right relationship between the world and its Creator (e.g. Isa 45:8, 23; Ps 85:4-13; 98:1-9). ${ }^{55}$ Additionally, righteousness is also a forensic concept. In relation to God, צדקה מדק occurs as the basis of his saving actions, ${ }^{56}$ which at times denotes the salvation of Israel through His judgments upon pagan nations that have

${ }^{50}$ See Von Rad, Old Testament Theology, 2:370-371.

${ }^{51}$ See Walton, Ancient Near Eastern Thought, 153.

${ }^{52}$ Von Rad, Old Testament Theology 1:371.

${ }^{53}$ Mark A. Seifrid, "Righteousness, Justice, and Justification," in New Dictionary of Biblical Theology, ed. T. Desmond Alexander and Brian S. Rosner (Downers Grove: Inter-Varsity, 2000), 742.

${ }^{54}$ Ibid. cf. Deut 6:20-25; Ps 7:6-11; 1 Sam 26:23;

${ }^{55}$ Seifrid, "Righteousness, Justice, and Justification," 741. The notion of righteousness as "right order" fits well in the ANE concept of ethical norms (see Walton, Ancient Near Eastern Thought, 152-153).

${ }^{56}$ Cf. Ps 31:1; 36:6, 10; 72:2; 89:16; 103:17; 111:3; 119:40; 143:1, 11; 145:7; Isa 42:21. 
oppressed Israel. Both salvation and judgment rests upon the basis that YHWH is the judge pronouncing judgment or vindication. God's righteousness often appears in a forensic context in which $\mathrm{He}$ acts as the judge to restore order in the society (Ps 9:4,8; 50:6; $96: 13 ; 99: 4)$ and to defend those who are wrongly treated or afflicted (Ps 103:6). More importantly, the concept of righteousness in the OT is closely tied to the character of God..$^{57}$ Skinner asserts that "in the OT righteousness is never predicated of any other deity than $\mathbf{J}$ [YHWH], the God of Israel. It appears to be regarded not as a natural attribute inseparable from the very notion of Godhead, but as one which $\mathbf{J}$ alone has proved Himself to possess in the positive revelation of Himself through the history of Israel." 58

In short, righteousness is not merely founded upon legal codes, even though the Law does reflect the notion of righteousness. Rather, righteousness is founded upon a relationship with YHWH, encompassing the moral, creational, and forensic aspects. More importantly, righteousness is rooted in the character of God, demonstrated through His acts of law giving, which is to create a society that exhibits right relations and order.

is most commonly rendered as justice or judgment, dealing with "judicial activity at every level." ${ }^{59}$ However, Birch rightly pointed out that the meaning and application of the word transcends the judicial level and has "a broader meaning dealing with the rights due to every individual in the community, and the upholding of those rights." 60 Weinfeld argues

\footnotetext{
${ }^{57}$ Similarly, Walton maintains that Israel developed their theology of morality by means of the "instigation of guilt" through the Torah and "the mandate to imitate God, thus relocating the foundation of ethical responsibility (in the character of God) and thereby fostering a sense of abstract right and wrong. ... The high ideal of imitating the deity did not exist in any other ancient Near Eastern culture" (Walton, Ancient Near Eastern Thought, 154-55).
}

${ }^{58}$ Skinner, "RIGHTEOUSNESS IN OT," 278-279.

${ }^{59}$ Birch, Let Justice Roll Down, 155.

${ }^{60}$ Ibid. cf. Weinfeld, Social Justice, 35. that to the prophets, doing מששפט refers to "actions of social injustice." 61

Therefore, righteousness and justice can be seen as closely related concepts. Weinfeld concludes that the two words are "bound up with actions on behalf of the poor and the oppressed." ${ }^{2} 2$ The basis for such concerns for the poor and oppressed in Israel is founded upon the notion that every Israelite belongs YHWH. ${ }^{63}$ As such, every Israelite is endowed with equal dignity and equal rights as citizens of God's kingdom. In Isaiah, YHWH addresses the oppressed and the poor as "my people" (Isa 3:15, 10:2). Isaiah made it clear that injustice was condemned not so much for the sake of injustice itself but because injustice was done towards the poor who are God's Thus, justice and righteousness has an ontological base - the identity and character of the nation of Israel as God's people. Therefore, righteousness and justice is the upholding of social justice. Social justice must be maintained based upon the equal rights and dignity endowed by YHWH to every individual within the society. Isaiah's use of righteousness and justice fits well with this understanding of social justice.

Wright pointed out that Israel's responsibility to uphold social justice explicitly stems from YHWH's act of righteousness in redeeming Israel from the oppressive hands of Egypt. ${ }^{64}$ Israel's foundation for social life must be grounded upon righteousness and justice. Hanson, following Fensham-Weinfeld-Patterson's study on the concept of social justice among Israel's neighbours in the Ancient Near East, observed the distinctive character of social justice in Israel as compared to her neighbors. For one, the idea of social justice in Mesopotamia, Egypt, and Canaan was grounded in a societal structure borne out of myths and royal ideology, while that of Israel

\footnotetext{
${ }^{61}$ Weinfeld, Social Justice, 35.

${ }^{62}$ Ibid., 25-44.

63"If you lend money to any of my people (עפכמי) with you who is poor, you shall not be like a moneylender to him, and you shall not exact interest from him" (Ex 22:25).

${ }^{64}$ Wright, Living as the People of God, 141-2.
} 
was grounded on a societal structure built on "epic and covenant." ${ }^{55}$ Hanson stated that as it regards Israel's neighbors, their social institution is built upon myth that carries the close interplay between order and chaos of which the king was deemed as the "bulwark against chaos." Therefore, for Israel's neighbors, the need to maintain the hierarchical social structure through social justice is viewed purely as a way to secure the authority of the king's rule over his people. Inevitably, social justice is presented and maintained with the pragmatic goal of maximizing the king's authority so as to guarantee social order, peace, and prosperity. On the contrary, the Bible pictures Israel as a people founded upon the saving acts of a compassionate God, delivering them from the social political oppression of Egypt. Therefore, righteousness and justice must be maintained in Israel not as it pertains to a pragmatic promoter of economic prosperity, social peace, or royal authority, but as a response to imitate the character and works of the God who has delivered them out of Egypt - the God who has declared himself as righteous and just (Deut 32:4; Ps 89:14). In Wright's words, "having been put 'right,' so to speak, they [Israel] were to maintain righteousness.... Having experienced justice, they were to do "justice." 66 Thus, justice and righteousness must run through their veins and expressed in their social relationships as expressed in the areas of their stewardship of wealth, their attitude toward ill-gotten gains, their honesty towards other's reputation, and their treatment of the economically deprived.

However, Israel had violated YHWH's demands for righteousness and justice within their social relationships. From Isaiah's standpoint, social injustice is both a sin of commission and omission. On the one hand, Israel was guilty in their flagrant oppression of the poor and needy, as shown in their treatment of the widows and the poor (1:21-23), their greedy appropriation of land belonging to the poor $(5: 8-10)$, and their plunder of the poor

\footnotetext{
${ }^{65}$ Leclerc, Yahweh is Exalted, 35-36.

${ }^{66}$ Ibid.
}

(3:14). Furthermore, they were guilty of theft and bribery (1:23) as well as malice and slander (32:7). On the other hand, Israel was also condemned for their neglect in maintaining social justice, as shown in their neglect of the needs of the hungry and thirsty (32:6). This neglect was clearly "typified" by their drunkenness and luxurious lifestyle. ${ }^{67}$

Here, Davies is doubtful that Isaiah was appealing to legal provisions in these text. He pointed out that there were neither sobriety laws nor specific laws against accumulation of wealth and luxury in Israel nor were there any specific laws against the accumulation of the land. ${ }^{68}$ In response to those who sees a connection between the rebellious son in Isaiah 1:2-3 and Deuteronomy 21:18-21, Davies asserts that the punishments for gluttony and drunkenness in Deuteronomy 21:18-21 is "for selfishness and greed, or for anti-social drinking habits" rather than for the stubbornness and rebelliousness of a son. ${ }^{69}$ Davies's suggestion here aims to sever any association of a stubborn (ררוס) and rebellious (הרומ) son from drunkenness and gluttony as portrayed by the law in Deuteronomy 21:18-21. This would then throw into question any correspondence between Isaiah's indictment and the legal codes. Opposed to such semantic view of legal statutes, ${ }^{70}$ Burnside argues that gluttony and drunkenness in Deuteronomy 21:18-21 is a "typification" of a stubborn (ררוס) and rebellious (הרומ). Accordingly, the seriousness of a son's stubbornness and rebelliousness, typified by a lifestyle of drunkenness and gluttony, is to be viewed in context of the covenant. Within Deuteronomy's covenantal framework, parental instructions were to be seen in close relations to the teaching of YHWH's character and commands (Deut

\footnotetext{
${ }^{67}$ See Burnside's explanation of "typification of action" in Signs of Sin, 19.

${ }^{68}$ Davies, Prophecy and Ethics, 26-27.

${ }^{69}$ Ibid., 60 .

${ }^{70}$ Davies asserts that "there is no linguistic similarity" between Deuteronomy 21:18-21 and the theme of rebellious and stubborn son in Isaiah 1:2-3 (see Davies, Prophecy and Ethics, 60).
}

${ }^{71}$ Burnside, Signs of Sin, 47-55. 
4:9-10, 6:7). As a result, a son's stubborn (ררוס) refusal to listen to "parental instruction in regard to YHWH's commands" has "overtones of apostasy." 72

In Isaiah 5:11-12, when Isaiah condemned the Israelites for their drunkenness and opulence, it was explicitly in context of their negligence to the "deeds (פַעַ) of the LORD" and "the work of His hands." On the one hand, their indulgences had affected their dullness in spiritual perception. As a result, they fail to recognize God's work of "on-hastening judgment" upon them. ${ }^{73}$ On the other hand, this dullness to the "deeds of the LORD" is also a failure to recognize the Lord's way of justice, which $\mathrm{He}$ had commanded them to follow. ${ }^{74}$

Woe to those who rise early in the morning that they may pursue strong drink, who stay up late in the evening that wine may inflame them! Their banquets are accompanied by lyre and harp, by tambourine and flute, and by wine; But, they do not pay attention to the deeds of the LORD, Nor do they consider the work of His hands (Isa 5:11-12, ESV; italics mine).

The connection between drunkenness and justice is made explicit in Isaiah 28:7, for the Israelites "are confused by wine, they stagger from strong drink; they reel while having visions, they totter when rendering judgments

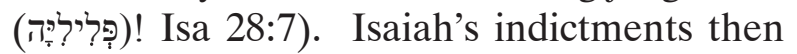
echo the paradigm case of a rebellious and stubborn son typified by drunkenness and gluttony. Even without an explicit reference to the law, the indulgences of God's people were cast as rebellion against YHWH by violating his demand for righteousness and justice. Isaiah's indictment against the Israelites was not a novel invention, albeit it was a fresh application. He called for radical reform in order that the Israelites might return to their true responsibility as God's chosen people-a

\footnotetext{
${ }^{72}$ Ibid., 51.

${ }^{73}$ Edward Young, The Book of Isaiah, Chapters 1-18 (Grand Rapids: Eerdmans, 1965), 1:210.

${ }^{74}$ In Deuteronomy 32:4, YHWH's perfect deed (פעֵעל) is

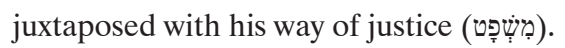

responsibility of maintaining social justice in light of their covenantal relationship with YHWH. ${ }^{75}$

Not only did Isaiah point out Israel's failure to uphold social justice, he highlights the fact that only YHWH himself will be able to establish the ideals of righteousness and justice $(5: 16 ; 26: 9 ; 33: 5)$ in their midst. It is important to note that Isaiah's call for reform is not so much a call to social action on Israel's part but a call to return to YHWH, their God, who is the source of righteousness and justice. Only if a turning to YHWH happens can a right kind of lifestyle and social ethics follow.

\section{Syncretism, Idolatry, and Pride}

Come, house of Jacob, and let us walk in the light of the LORD. For You have abandoned Your people, the house of Jacob, because they are full from the east, and they are soothsayers like the Philistines, and they strike bargains with the children of foreigners. Their land has also been filled with silver and gold and there is no end to their treasures; their land has also been filled with horses and there is no end to their chariots. Their land has also been filled with idols; they worship the work of their hands, that which their fingers have made. So the common man has been humbled and the man of importance has been abased, but do not forgive them. Enter the rock and hide in the dust from the terror of the LORD and from the splendor of His majesty. The proud look of man will be abased and the loftiness of man will be humbled, and the LORD alone will be exalted in that day (Isa 2:5-11).

These few verses introduce the next major portion of Isaiah's indictment against the Israelites-their failure in the religious sphere. In chapter one, Isaiah briefly, but explicitly high-

\footnotetext{
${ }^{75}$ Leclerc pointed out that with the rise of the monarchy, the centralization of power and stratification of the society into classes, the prophet's role was to call Israel back to the theocentric, covenantal, and egalitarian society, where equity and justice was maintained (see Leclerc, Yahweh is Exalted, 36).
} 
lighted YHWH's rejection of Israelite cultic practices. As mentioned previously, this rejection was rooted in their failure in upholding righteousness and justice. The focus shifts next to Isaiah's charge against their syncretistic practices within the religious realm. ${ }^{76}$

Isaiah's charge begins with an exhortation to walk in the light of the LORD followed by a clear description of how Israel had deviated from that pathway of light. God's people was "full from the East" and practicing divination like the Philistines. The phrase מקדרם מָלִאי is difficult to translate. However, if it is understood to be parallel to the following stich, then it is likely to have a synonym for the word ענן (divination) or at least a similarly intended meaning. ${ }^{77}$ Thus, the Israelites were indicted for importing what the Law strictly forbade (cf. Lev 19:26; Deut 18:9-14)—divination, from the East (Babylon and Assyria) and from the Philistines. Even though God's people maintained their YHWH-oriented religious practices, they continued to introduce syncretistic practices into their worship. From a subtle assimilation of divination into daily lives, Israelite apostasy became full blown when they began bowing their knees to idols. It was against such idolatrous practices that God vehemently leveled his charges via sarcasm through the prophet Isaiah (Isa 10:10-11; 17:7-11).

It is interesting to note how Isaiah views the concept of idolatry. The passage in Isaiah 2:6-18 moves from Israel's pagan practices to their idolatry and to the denunciation of the pride of man. It is this movement towards the pride of man that reveals to us that which Isaiah considered to be the source of all pagan practices and idolatry.

\footnotetext{
${ }^{76}$ It is important to note that Israel's syncretistic practices went beyond their religious practices into both political and social spheres. The religious sphere, however, will be the one we will focus our attention on.

${ }^{77}$ Some translators thought that miqsām, "divinations," has dropped out due to haplography, since it is similar to miqqedem, "from the east the word" (see Oswalt, The Book of Isaiah, 122).
}

Isaiah laid down his charges plainly. It was not merely the worship of idols that was abhorrent, but the worship of "the works of their hands, that which their fingers have made." Oswalt observes that nowhere else in Scriptures is the foolishness of idolatry so emphasized as that displayed within the book of Isaiah. ${ }^{78}$ Idolatry is man bowing down to the work of his own hands. Instead of bowing down to YHWH, who alone is the exalted One and the Sovereign LORD of the world, the Israelites bowed down to the work of their own hands. These actions were portrayed in sharp contrast to true worship that exalts the YHWH alone (v. 11). Barton pointed out that the pride of man is inextricably bound to idolatry because of man's refusal to submit to the natural order of God's creation. $\mathrm{He}$ saw the Lord's place in the world and everything else beneath Him as the natural order of creation. Thus, pride and idolatry is closely related together since man refused to submit to this natural created order and instead, worshiped a counterfeit order that he establishes for himself. ${ }^{79}$ Therefore, self-assertion is the hallmark of pride and arrogance.

However, this study seeks to defer from Barton's point that natural law serves as the basis of Isaiah's ethical indictment; the indictment goes much further. It must be clarified that idolatry was not detestable simply because the Israelites disregarded the "proper order of the world". ${ }^{80}$ The problem is unlike a child messing up his room right after his mother had put things in order. The mother then becomes infuriated over the child's unruly behavior of messing up. In contrast, idolatry is detestable to YHWH, not so much because it upsets the natural order that $\mathrm{He}$ has set in place, but because He has demonstrated Himself as the Sovereign over all in His deliverance of Israel from Egypt and the establishment of their

\footnotetext{
${ }^{78}$ Oswalt, Isaiah, 34.

${ }^{79}$ Barton, "Ethics in Isaiah of Jerusalem," 8-9. Also, Isaiah frequently juxtaposes the pride and arrogance of man with the definite exaltation of the LORD. Cf. 2:6-17. This elucidates that the pride of man is the antithesis of YHWH exaltation.

${ }^{80}$ Ibid., 11.
} 
entire nation in the land of Canaan. ${ }^{81}$ Idolatry is abhorrent in God's eyes because the Israelites had rebelled against the One who has nurtured them. They have failed to recognize their Sovereign (Isa 1:4-5). A proper understanding of idolatry must be highlighted within the context of a proper understanding of covenant relationships, which YHWH established with Israel (Isa 17:10). It is through just such a covenantal relationship - a relationship which Israel had proven time after time that she does not deserve and one which YHWH established out of his understanding of the perversity and absurdity of Israelite idolatry.

Pride, then, is more than an attitude of arrogance and conceit. It is ultimately a show of contempt against YHWH and a rejection of His rightful place in the lives of the Israelites. Isaiah spared no effort to accuse them of such contempt. In their pride, the Israelites blasphemed against $\mathrm{YHWH}$ and rebelled against His Sovereign presence (Isa 3:8). In their pride, their daughters held their heads up high, adamantly trusting in their own security and luxury (Isa 3:16-26). In their pride, they rejected the chastisement of God and refused to turn back to Him (Isa 9:8-13). Isaiah leaves no doubt that such pride and arrogance would incur the judgment of God, which brings about a reversal of situation. Instead of reveling in their luxuries and adornments, God will extend to them both shame and poverty (Isa 3:24-26).

\section{Empty Trust and Futile Alliance}

Isaiah's most vivid elucidation of Israelite pride and arrogance comes in terms of their foreign policies. Until 750 B.C., both the northern and southern kingdoms had enjoyed a time of unparalleled peace and prosperity since the time of Solomon's reign. Complacency was in the air, thick with presumptions

\footnotetext{
${ }^{81}$ As evidenced by the formulaic use of ידע: ידודה" with "כי אבי (see Douglas K. Stuart, Exodus, The New American Commentary [Nashville: Broadman \& Holman, 2006], 2:36-37).
}

that YHWH was blessing both kingdoms. ${ }^{82}$ However, when Tiglath-pileser III came into the scene in 745 B.C, the Assyrian empire expanded under his leadership and dashed the complacencies of both Northern and Southern kingdom. It was against this backdrop of the immense pressure of the Assyrians and the strong threat they posed to God's peoples survival in which their sins became most clearly exposed.

After Isaiah had declared that YHWH will bring down the lofty pride of man as shown in their idolatry and self-assertion, Isaiah moves on to give a clearer description of how pride is shown in both of the kingdom's political relationships. Their pride became crystallized in terms of their trust in human schemes and blatant refusal to trust in God. Oswalt righty observed that chapters 7-39 revolve around the theme of trust. ${ }^{83}$ This theme is developed by contrasting Judah's empty trust in every other available entity other with the notion that YHWH alone is worthy of their trust.

First, they had trusted in human leadership and the glory of man. For that, YHWH would remove competent leaders and allow societal structure to breakdown into disorder (3:1$5)$. There would be a day when God's people would desperately search for a leader but none will be found (3:6-7). Furthermore, Isaiah highlights their foolishness in trusting human rulers. The very leaders whom they trust are those who were leading them astray (3:12). These were mere "children" and "capricious" rulers $(3: 4,5,12) .{ }^{84}$ Yet, Judah continued to look to them for leadership. The theme of Judah's empty trust in human leadership continued its echo in Isaiah's continuing negative portrayal of the leaders. Their leaders are those who have become oppressors (3:13-15). They are those who have enacted evil laws to

\footnotetext{
${ }^{82}$ See Isa 32:1-20. Such complacent attitude also drew fire from Amos' message (cf. Am 5:18-20).

${ }^{83}$ Oswalt, Isaiah, 56 and 193.

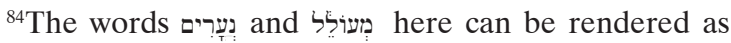
"lad" and "children" respectively. The sense here is figurative rather than literal and it denotes the incompetence of Israel's leadership (cf. ibid., 138).
} 
oppress the poor and needy (10:1-2). They were proud drunkards whose souls were so heavily invested in wine, that they were unable to make sound judgments (28:1-13). The only people whom they were capable of instructing were babes (28:9). Therefore, with lucid sarcasm, Isaiah pointed out the senselessness of trusting in-house oppressors to deliver the Israelites from foreign oppressors. This is like calling upon wolves to deliver the sheep. However, God's people refused to listen. Though YHWH had sent His judgment upon His people, they refused to turn back to Him. Instead, they continue to follow blindly the guidance of leaders who were leading them astray (9:14-16). For that, God again promised that He would remove these leaders from their midst, so that the futility of their trust in human leadership would be exposed.

Secondly, not only did Isaiah accuse the people for trusting in human leadership, he further indicted them of trusting in foreign leadership and foreign powers. This comes in terms of seeking of foreign counsels and the forming of alliances unsanctioned by God.

When Ahaz, Judah's ruler, came face to face with the threat of a combined invasion of Syria and the Northern Kingdom, he was faced with an opportunity to trust God for deliverance (Isa 7:1-16). However, he did not. Instead, he turned to Assyria for help (2Kgs 16:7-9). Therefore, Isaiah declared that the Assyrians would not be Judah's aid but rather their worst enemy (8:7-8). God would turn their dependence into their oppression by the very hand of those in whom they placed their trust (10:6).

As the threat of Assyrian power grew, Judah in the south began to shift her dependence unto Egypt. ${ }^{85}$ The southern kingdom, again, instead of looking to YHWH, turned to foreign powers for help and advice (chapters 30-31). Isaiah not only denounced their attempt to seek advice from the Egyptians, but also pointed out the foolishness and futility of such consultations.
The princes of Zoan are mere fools; the advice of Pharaoh's wisest advisers has become stupid. How can you men say to Pharaoh, "I am a son of the wise, a son of ancient kings?" Well then, where are your wise men? Please let them tell you, and let them understand what the LORD of hosts has purposed against Egypt. The princes of Zoan have acted foolishly; the princes of Memphis are deluded; those who are the cornerstone of her tribes have led Egypt astray. The LORD has mixed within her a spirit of distortion; they have led Egypt astray in all that it does, as a drunken man staggers in his vomit. There will be no work for Egypt which its head or tail, its palm branch or bulrush, may do (Isa 19:11-15).

The Egyptian advisers, reputed for their wisdom ${ }^{86}$ were denounced as mere fools. Since the Egyptians could not discern YHWH's purpose for Egypt, they would lead Egypt astray. In this short passage, YHWH's wisdom and sovereign control over all the earth stands in sharp contrast to the limited wisdom of the Egyptian leadership. Since the Egyptian leadership would not be able to secure and guide their own country, how then could they provide security and guidance for the Israelites? Thus, Isaiah undermined Egypt in order to emphasize the folly of God's people for trusting in her counsel.

Not only did Judah go after the counsel of foreigners, Isaiah continues to denounce their desire to form alliances with foreign nations in order to find some sort of security against Assyria. With biting words, Isaiah denounces their constant desire to form alliance with Egypt as an act of rebellion against YHWH:

"Woe to the rebellious children," declares the LORD, "Who execute a plan, but not Mine, and make an alliance, but not of My Spirit, in order to add sin to sin; who proceeded down to Egypt without consulting $\mathrm{Me}$, to take refuge in the safety of Pharaoh and to seek shelter in the shadow of Egypt!" Therefore the safety of Pharaoh

${ }^{86}$ Isaiah 30:1, “adding sin to sin" (see also ibid., 370). 
will be your shame and the shelter in the shadow of Egypt, your humiliation. "For their princes are at Zoan and their ambassadors arrive at Hanes. "Everyone will be ashamed because of a people who cannot profit them, who are not for help or profit, but for shame and also for reproach. "The oracle concerning the beasts of the Negev. Through a land of distress and anguish, from where come lioness and lion, viper and flying serpent, they carry their riches on the backs of young donkeys and their treasures on camels' humps, To a people who cannot profit them; Even Egypt, whose help is vain and empty. Therefore, I have called her 'Rahab who has been exterminated"” (Isa 30:1-7).

From this passage, it is clear that Isaiah saw the act of seeking an alliance as sin. Their alliance with Egypt was the ultimate assertion of autonomy from God. Not only did Judah not consult God, they willfully delighted in finding security in the arms of Egypt and in the safety of her leaders. Thus, they were adding $\sin$ upon $\sin .^{87}$ The imagery portrayed by Isaiah here is the picture of obstinate children, bent on doing their own will, set on disregarding YHWH. Moreover, the act of making an alliance implied a lack of trust in YHWH who has constantly revealed himself as one worthy of trust. Instead of trusting in YHWH, the Israelites were determined to go after "a people who cannot profit them" (vv. 5 and 6). ${ }^{88}$ It is important to note that in Isaiah's message, there is the frequent juxtaposing of the human and political failure with the righteous reign of $\mathrm{YHWH}$ and His ability to deliver. ${ }^{89}$ Chapters 2-12 juxtapose numerous themes that illustrate the tension between the ideals of the kingdom of God and human kingdoms with ravenous appetite for power. This sets YHWH's divine sovereignty and ability in contrast with human leadership and their inadequacies. It further highlights the fool-

\footnotetext{
${ }^{87}$ See Motyer, The Prophecy of Isaiah, 245.

${ }^{88}$ The repetition of the clause 'al- 'am lō'-yô' îlû heightens the folly of trusting in foreign powers.

${ }^{89}$ See Smith, Isaiah, 123.
}

ishness of reliance in man and things, rather than on God alone. Israel's reliance on anything or anybody, rather than on God alone, provoked His ire against them (Isa 31:1-3).

Some scholars have struggled to make sense of how Isaiah's wisdom language fits into his ethical framework. They perceived that Isaiah was heavily influenced by some kind of wisdom tradition..$^{90}$ From that supposition, they posit various theories about the function of wisdom language and even about Isaiah's occupation before his call to prophetic ministry. However, furnished by an understanding of the theme of trust which forms that backdrop to Isaiah's wisdom language, it seems that Isaiah's aim was to demonstrate the folly of trusting in human powers.

Earlier, it was mentioned that Judah's foreign policy was the outworking of their pride and contempt against YHWH. Yet, it is interesting to note that Isaiah not only laid his charge against pride manifested among the commoners, as shown in their dependence and trust in human leaders and the worship of idols, but he was equally vehement in accusing those in power for their pride and contempt against YHWH. It can be safely deduced that foreign policies and decisions toward alliance rest largely on the prerogative of Israelite leaders. ${ }^{91}$ Yet, Isaiah did not explicitly pronounce that the responsibility falls on the leaders alone. On the contrary, he pronounced that the entire people have rejected YHWH and refused to depend upon Him (8:5-8). Isaiah is clear to his point, the people, comprising of both leaders and commoners, had acted in solidarity against YHWH.

In addition, both leaders and commoners fell into the trap of "practical humanism." They were more eager to depend on the works of their hands, the weapons and the strength of the walls to maintain their survival than they were willing to depend upon YHWH (22:8-19). In short, the Israelite's fidelity to

\footnotetext{
${ }^{90}$ Davies, Prophecy and Ethics, 29-35.

${ }^{91}$ This can be seen from Isaiah's specific accusation laid against both Ahaz (7:3-9) and Shebna (22:15-19).
} 
every and other entity rather than YHWH is central to Isaiah's indictment against them. This misguided and empty trust of theirs manifests itself politically in ways which they trust in human leadership, foreign alliances or anything man-made (which, interestingly enough, also clearly ties in to the problem of their idolatry). Yet, according to Isaiah, such a futile trust and ensuing rejection of $\mathrm{YHWH}$ is clearly a manifestation of their pride and contempt against Him.

\section{Synthesis}

In the social sphere, it can be observed and stated that Isaiah was very much concerned with the "ethical behaviors" evidenced among the people of God. This includes what the Israelites ought to do, and ought not to do, in terms of social justice. In the religious and political spheres, Isaiah shifts gear from their behaviors to their attitudes, from their outward actions to their inclinations of the heart and from their deeds to their allegiances. These come in terms of Isaiah's accusation against Israelite idolatry, their empty trust accompanied by blatant refusal to trust in YHWH. Isaiah describes all these behaviors and attitudes as acts of rebellion against YHWH. Furthermore, Isaiah does not separate social ethics from the religious or the political. He perceives that these three areas were integral to Israel's ethical ideal. By stating that Isaiah assumes that the Israelites knew what was expected of them immediately opens up the arena of debate on the dating and function of Isaiah the prophet. Is Isaiah taking the role of an inventor of ethical monotheism or the role as a covenant reformer? It is beyond the scope of this article to deal with such pressing issues. However, it should be stated that, from a literary standpoint, Isaiah's message would be senseless if he had not assumed that his audiences were operating on the same ethical plane as himself was doing. ${ }^{92}$ The vast number of passages where this is intimated gives fur-

\footnotetext{
${ }^{92}$ So R. E. Clements argues on the basis that "the prophets clearly expected their hearers to know what they were talking about" (see Clements, Prophecy and Covenant, 15).
}

ther and ample evidence that Isaiah specifically calls for the people to perform what they ought to do and that they knew what those actions entailed. Yet, this does not mean that Isaiah did not shed new light into their sinful ways of living in bringing these new charges to the people; charges within prophetic formulations which would have caught the people by surprise.

The difficulty now lies in trying to determine the relationship between social justice, idolatry, and the people's empty trust in anything but YHWH within the prophet Isaiah's unfolding ethical framework. It has already been clarified that pride is clearly manifest in the Israelite idolatry and their dependence upon human and foreign leadership as well as political alliances. In a way, Israel's idolatry, their dependence upon human leaders/ alliances and their refusal to rely on YHWH alone, nothing less than a manifestation of "humanistic" pride. Nevertheless, in order to discover Isaiah's ethical basis, we must examine the nature of the relationship between social justice and pride in accord with Isaiah's perspective.

At this juncture, it would be appropriate to mention Barton's research again. Barton suggests that Isaiah's ethical basis was the natural law that envisioned that YHWH should occupy the highest place in creation. He attempts to reconcile both legal and wisdom elements found in Isaiah under the notion of natural law. Correspondingly, pride, then, is the root of all $\sin .{ }^{93}$ Thus, human pride aims to supplant the rightful position of $\mathrm{YHWH}$ within the cosmos and to reverse the natural order of the place of divinity. Pride caused the Israelites to turn the rightful worship of the sovereign YHWH into worshiping the work of their hands. Further, pride aimed to reverse the natural order of human society. ${ }^{94}$ Thus, pride resulted in the overemphasis of one's importance which manifests itself in concrete behaviors such as the indulgence of

\footnotetext{
${ }^{93}$ Barton, Ethics in Isaiah, 8.

${ }^{94}$ Here, Barton did not describe the nature and origin of such an order.
} 
luxuries, the accumulation of riches, and the oppression of the poor and widowed. ${ }^{95}$ Pride also resulted in human folly such that men were deluded to seek their security in people and things apart from YHWH. ${ }^{96}$ In short, Barton views every sin, which Isaiah accused the Israelites of committing in the social, political, and religious sphere, is to be subsumed under the broad category of pride. He sees pride as the rejection of the true natural order of things.

Barton's study has certainly shed light and contributed greatly to the discussion of Isaiah's ethics. However, Barton's solution is unsatisfactory. There is little evidence within Isaiah which ties both pride and injustice intimately together. Even if it could be argued that pride is manifested in the indulgence of luxuries which is then related to injustice (Isa 3:16-26), how should one determine the order of priority given to either pride or injustice? How should one determine if pride should be subsumed under injustice or injustice under the rubric of pride?

In contrast, it was demonstrated that the charge of "rebellion against YHWH" is broad enough a heading to encompass what Isaiah considers as demonstrative of Israel's sins in the social, political and religious realms. This can also be viewed in Isaiah use of the words (rebel or transgress), and סָרֵ (be rebellious) ${ }^{99}$ to depict Israel's rebellion against YHWH as well as Isaiah's attempt to cast the Israelites as a rebellious son as typified by Deuteronomy 21:18-21. In the first few verses of his opening address, Isaiah vividly describes the state of Israel's relationship with YHWH. It was a state of estrangement and rebellion (1:2-3). These statements, regarding Israel's rebellion and rejection of $\mathrm{YHWH}$, rightly then forms the foundation from which Isaiah recognized and

\footnotetext{
${ }^{95}$ Ibid., 9-10.

${ }^{9}$ Ibid., 11-12.

${ }^{97} \mathrm{Cf}$. Isa $1: 2,28$.

${ }^{98} \mathrm{Cf}$. Isa $1: 4$.

${ }^{99} \mathrm{Cf}$. Isa $1: 23 ; 30: 1$.
}

evaluated Israel's social, political and religious life. ${ }^{100}$ Isaiah's indictments against the Israelites' social, political, and religious life then is the elaboration of what he meant by rebellion against YHWH. This point is significant. Sin was not simply a violation of the natural order of things established by YHWH, as Barton proposed. Rather, it is rebellion against YHWH himself. These two points are similar but are fundamentally and remarkably different in nature. The former assumes that YHWH is outside of the realm of natural law as if the violation of the natural law has little to do with YHWH Himself. The latter statement envisions Israel's sin as fundamentally attacking the YHWH's being and character. From Isaiah's perspective, the Israelites were not guilty of merely violating some laws, as some scholars conclude in the study of Isaiah's tradition. ${ }^{101}$ They were guilty of turning against the Sovereign LORD, the God who has called them forth as His holy people and draw them close as children and sons. Such rebellion is against the very person and character of YHWH. For that, YHWH himself will guarantee their judgment which is something clearly envisioned in Isaiah's messages.

Therefore, in this article, it is suggested that fidelity to YHWH (and the attendant notion of rebellion against YHWH) is the ethical basis from which Isaiah operates. Israel was expected to be faithful to YHWH. Their faithfulness must be acted out in upholding social justice as it stems from YHWH's historical

\footnotetext{
${ }^{100}$ There is a consensus that Isaiah chapter 1 constitutes an introduction of some sort (see Brevard S. Childs, Isaiah, 9).

${ }^{101}$ These scholars try to make a distinction between casuistic laws and apodictic laws, and attempt to discover some kind of association between the two and Isaiah's message (cf. Anthony Phillips, "Prophecy and Law," in Israel's Prophetic Tradition: Essays in Honour of Peter Ackroyd, ed. Richard Loggins, Anthony Phillips, and Michael Knibb [Cambridge: University Press, 1982], 217-232; Gene M. Tucker, "The Law in the Eighth-Century Prophets," in Canon, Theology, and Old Testament Interpretation, ed. Gene M. Tucker, David L. Petersen, and Robert. R Wilson [Philadelphia: Fortress 1988], 201-215). Barton would fall into this category as well except that he chose to examine Isaiah's ethical basis and not on Isaiah's source and tradition.
} 
act of deliverance of Israel from the oppression of Egypt which was an outworking of His character of compassion and justice. Moreover, Isaiah also lashed out at the Israelites' infidelity through the practice of idolatry. In their idolatry, they have "forgotten the God of your salvation and have not remembered the rock of your refuge" (Isa 17:7-11). Idolatry is thus seen as their prideful disregard for the God who has saved them. Rather, they chose to regard the works of their hands and to consult false gods rather than the true and living YHWH (Isa 8:19). Even when YHWH continues to demonstrate that $\mathrm{He}$ alone is sovereign, just, powerful, and faithful, thus worthy of their trust and allegiance, Israel chose not to turn to Him for help but continued to put their trust in human leadership and foreign alliances. This too is an act of rebellion and infidelity against YHWH (Isa 30:1-7). In addition, Isaiah frequently contrasts the sovereignty of YHWH and His righteous character over and against all other created things (idols and humans, etc.). Together with the charge of rebellion, these passages shows that Israel's infidelity was shown in their rejection of YHWH's sovereign and righteous character and their adamant dependence on weak and fallible human powers.

In conclusion then, the ethical basis from which Isaiah launched his indictment upon Israelite is rooted in their necessary fidelity toward YHWH. The fidelity expected of them is inextricably bound to YHWH's revelation of His character and works through history. Israel must work out their fidelity not only in their religious life but also in their social and political life. To Isaiah, the religious, social, and political aspects are inseparable and grounded in the common denominator of the person and works of YHWH. To speak of Isaiah's ethics is to speak of a way of living expected by YHWH incumbent upon all of His people. In the clarification that biblical ethics is a response to YHWH's character and works, Christopher Wright states that "ethics is not an agenda, a means to an end, an inflexible law, self-fulfillment, or any of the other terms that may secondarily describe various human formulations of it. It is primarily a response to God, who he is and what he has done." 102 Only then, we can rightly understand that Isaiah's ethics is an inescapable echo of Leviticus 19:2, "Be holy because I, the LORD your God, am holy."

In short, Isaiah's ethical basis is primarily a theological one. The prophet anchored the social and political dimension of Israel's ethical life in the theological aspect of their relationship with YHWH. Without this theological understanding, the social and political aspects of ethics would make little sense to either Isaiah or to the Israelites.

Theology then, underpins both the legal and wisdom traditions of Isaiah. Even though Barton, this study believes, may have overstated his case, he has rightly pointed toward the direction that Isaiah's ethical injunctions rests upon the view that Israel had disregarded the "proper order of the world". ${ }^{103}$ Furthermore, Craig Bartholomew argues convincingly that "law and wisdom share an underlying and often tacit presupposition of a 'carved' creation order." 104 There is no conflict between law and wisdom because Yahweh is both creator and Torah-giver (covenant-initiator). ${ }^{105}$ As Bartholomew rightly states, "instruction from Yahweh would therefore not be seen to conflict with the way he ordered his creation, but would provide the ethical principles for discovery of that order." 106 A God-centered basis lies at the very heart of Isaiah's ethics.

${ }^{102}$ Christopher J. H. Wright, "Ethical Decisions in the Old Testament." in Walking in the ways of the Lord: The Ethical Authority of the Old Testament (Downers Grove: InterVarsity, 1995), 117.

${ }^{103}$ Barton, "Ethics in Isaiah of Jerusalem," 11.

${ }^{104}$ Bartholomew, Ecclesiastes, 91.

${ }^{105}$ See also Craig G. Bartholomew, "Covenant and Creation: Covenant Overload or Covenantal Deconstruction," Calvin Theological Journal 30, no. 1 (April 1, 1995): 11-33.

${ }^{106}$ Bartholomew, Ecclesiastes, 91. 


\section{Bibliography}

Barnes, Albert. Notes on the Old Testament: Isaiah. Vol. 1. London: Blackie \& Son, 1851.

Barton, John. "Ethics in Isaiah of Jerusalem.” Journal of Theological Studies 32 (1981): 1-18.

- Understanding Old Testament Ethics: Approaches and Explorations. Louisville, Kentucky: WJK, 2003.

Bartholomew, Craig G. Baker Commentary on the Old Testament: Ecclesiastes. Edited by Tremper Longman III. Grand Rapids: Baker Academic, 2009.

Birch, Bruce. Let Justice Roll Down: The Old Testament, Ethics and Christian Life. Louisville: WJK, 1991.

Burnside, Jonathan P. The Signs of Sin: Seriousness of Offence in Biblical Law. Vol. 364. Journal for the Study of the Old Testament Supplement Series. Sheffield: Sheffield Academic Press, 2003.

Childs, Brevard S. Isaiah: A Commentary. Edited by William P. Brown, Carol A. Newsom, and Brent A. Strawn. 1st ed. The Old Testament Library. Louisville: WJK, 2001.

Clements, R. E. Prophecy and Covenant. Studies in Biblical Theology No. 43. Naperville: Allenson, 1965.

Davies, Eryl W. Prophecy and Tradition: Isaiah and the Ethical Tradition of Israel. Journal for the Study of the Old Testament Supplement Series. Sheffield: Journal for the Study of the Old Testament, 1981.

Jackson, Bernard S. Studies in the Semiotics of Biblical Law. Vol. 314. Journal for the Study of the Old Testament Supplement Series. Sheffield: Sheffield Academic Press, 2000.

Lange, John and Peter Philip Schaff, et al. A Commentary on the Holy Scriptures: Isaiah. Bellingham: Logos Bible Software, 2008.

Leclerc, Thomas L. Yahweh is Exalted in Justice: Solidarity and Conflict in Isaiah. Minneapolis, Minnesota: Fortress, 2001.

Lindblom, J. Prophecy in Ancient Israel. Oxford: Blackwell, 1962.

McConville, J. G. Law and Theology in Deuteronomy. Vol. 33. Journal for the Study of the Old Testament Supplement Series. Sheffield: JSOT, 1984.

Mendenhall, George E. "Covenant Forms in Israelite Tradition." The Biblical Archaeologist 17, no. 3 (1954): 49-76.

Miller, Patrick D. Israelite Religion and Biblical Theology: Collected Essays. Sheffield: Sheffield Academic Press, 2000.

Motyer, J. A. The Prophecy of Isaiah: An Introduction \& Commentary. Downers Grove: InterVarsity Press, 1996.

Murphy, R. E. "Wisdom - Theses and Hypotheses." In Israelite Wisdom: Theological and Literary Essays in Honor of Samuel Terrien, edited by J. G. Gammie. Missoula: Scholars. 1978.

Oswalt, John. The Book of Isaiah, chapters 1-39. NICOT. Grand Rapids: Eerdmans, 1986. 
Phillips, Anthony. "Prophecy and Law." In Israel's Prophetic Tradition: Essays in Honour of Peter Ackroyd, edited by Richard Loggins, Anthony Phillips, and Michael Knibb, 217-232. Cambridge: University Press, 1982.

Seifrid, Mark A. "Righteousness Language in the Hebrew Scriptures and Early Judaism." In Justification and Variegated Nomism: The Complexities of Second Temple Judaism, edited by D. A. Carson and Peter T. O'Brien. v140th edition. Vol. 1. Wissenschaftliche Untersuchungen Zum Neuen Testament. Grand Rapids; Tübingen: Baker Academic; Mohr Siebeck, 2001.

- "Righteousness, Justice, and Justification." In New Dictionary of Biblical Theology, edited by T. Desmond Alexander and Brian S. Rosner. Downers Grove: Inter-Varsity, 2000.

Skinner, John "RIGHTEOUSNESS IN OT." In A Dictionary of the Bible: Dealing with Its Language, Literature, and Contents Including the Biblical Theology, edited by James Hastings et al. New York; Edinburgh: Charles Scribner's Sons; T. \& T. Clark, 1911-1912), 273.

Smith, Gary V. Isaiah 1-39. Edited by E. Ray Clendenen. The New American Commentary. Nashville: Broadman \& Holman, 2007.

Sparks, Kenton L. Ancient Texts for the Study of the Hebrew Bible: A Guide to the Background Literature. Peabody: Hendrickson, 2005.

Stuart, Douglas K. Exodus. Vol. 2, The New American Commentary. Nashville: Broadman \& Holman, 2006.

- "The Old Testament Prophets' Self Understanding of Their Prophecy." Themelios 6, no. 1 (September 1980): 9-14.

Sweeney, Marvin. Isaiah 1-39: With an Introduction to Prophetic Literature. Vol. 16, The Forms of the Old Testament Literature. Grand Rapids: Eerdmans, 1996.

Von Rad, Gerhard. Old Testament Theology. 2 vol. Louisville: WJK, 2001.

Walton, John H. Ancient Near Eastern Thought and the Old Testament: Introducing the Conceptual World of the Hebrew Bible. Grand Rapids: Baker Academic, 2006.

Watts, James W. Reading Law: The Rhetorical Shaping of the Pentateuch. Sheffield: Sheffield Academic, 1999.

Wellhausen, Julius. Prolegomena to the History of Israel. Edinburgh: Adam \& Charles Black, 1885.

Weinfeld, Moshe. Social Justice in Ancient Israel and in the Ancient Near East. Jerusalem: Magnes Press, 2000.

Wenham, Gordon J. Story As Torah: Reading Old Testament Narrative Ethically. Grand Rapids: Baker Academic, 2004.

Wright, Christopher J. H. "Ethical Decisions in the Old Testament." In Walking in the Ways of the Lord: The Ethical Authority of the Old Testament, 117-145. Downers Grove: Inter-Varsity, 1995.

- Living as the People of God. Leicester, England: IVP, 2000.

. Old Testament Ethics for the People of God. Downers Grove: Inter-Varsity, 2004. 
Tucker, Gene M. "The Law in the Eighth-Century Prophets." In Canon, Theology, and Old Testament Interpretation, edited by Gene M. Tucker, David L. Petersen, and Robert. R Wilson, 201-216. Philadelphia: Fortress, 1988.

Young, Edward. The Book of Isaiah, Chapters 1-18. Vol. 1. Grand Rapids: Eerdmans, 1965. 